Vesna P. CIDILKO*

Humboldt Universität zu Berlin Berlin
Оригинални научни рад

Примљен: 16. 10. 2018.

Прихваћен: 14. 02. 2019.

\title{
ВАРИЈАЦИЈЕ БИОГРАФСКОГ ПРИСТУПА И ПИТАҢЕ ЖАНРА У САВРЕМЕНОЈ СРПСКОЈ ПРОЗИ
}

У излагању се на примерима из новије српске прозе истражује улога и функција биографског пре свега у кратким приповедним формама савремених аутора, при чему се, осим тематско-мотивске компоненте, критичкој анализи подвргава и жанровска структура датих књижевних текстова.

Кључне речи: хибридизација жанра, (ауто)биографска проза, глобална култура и типолошке и жанровске иновације, сећање као (ре)конструкција.

\section{Писаи не смије бити дискретан, поготово \\ у односу на себе и све своје. (Миљенко Јерговић, Селидба) \\ Уопште, чини ми се да рукописи зависе од невероватних доживљаја. (Горан Петровић, Разлике)}

\section{1. Уводне напомене}

Биографске и аутобиографске текстове налазимо већ у антици - подсетићемо на Платонову Апологију, неке од текстова Јулија Цезара ${ }^{1}$, Цицерона, Марка Аурелија ${ }^{2}$, или пак Confessiones Августина Хипонског. Спрега биографског као фактографског елемента и књижевног израза такође није нова. Током свог дугог развитка манифестовала се у различитим облицима, укључујући жанровску и садржајну детерминисаност појавних форми која педесетих и шездесетих година прошлога века доживљава кулминацију

\footnotetext{
*vesna.cidilko@staff.hu-berlin.de

${ }^{1}$ De bello Gallico (Записи о галском рату).

${ }^{2}$ Meditations или Самом себи, изворно написано на грчком.
} 
нормативним одређивањем аутобиографских текстова, да би се тек у новије време појавиле супротне тенденције за које је карактеристично наглашавање и пре свега допуштање тематски и формално отвореног карактера аутобиографских наративних структура ${ }^{3}$. Следствено томе, објективирајуће али и фикционалне стратегије, есејистичка или дневничка форма, одлике су како аутобиографског романа са почетка 20. века (Мецлер 2007: 58), тако и књижевних остварења нашег доба. Примере оваквих развојних линија налазимо и у савременој српској књижевности, код аутора од којих бих, када је реч о кратким књижевним формама, посебно навела Горана Петровића, Давида Албахарија, Радмилу Лазић ${ }^{4}$, али и Вука Драшковића и Драгослава Михајловића, поред низа других који су у задње време објавили аутобиографске романе или прозу са наглашеним уделом аутобиографских елемената, о чему ће у даљем излагању бити више речи. Велики број последњих година објављених биографија и мемоарске књижевности потврђује овај развојни ток не само у публицистици ${ }^{5}$, већ и у белетристици. Један од разлога за популарност мемоарског и исповедног штива, како то примећује Владимир Тасић, лежи у томе да је оно по дефиницији „аутентично”, што у данашњем свету књижевне индустрије представља вредност јер индустријском производу недостаје управо аутентичност (Тасић 2018: 4) 7 - а од књижевног текста се у принципу захтева да има одређених корелација са стварношћу, од аутора се чак понекад очекује да текст буде усаглашен са пишчевом биографијом, тврди Тасић, јер се захтеви масовног тржишта који се односе на веродостојност текста преносе на књижевност уопште, а пре свега на романе писане у широко схваћеном реалистичком кључу (Тасић 2018: 4).

\footnotetext{
${ }^{3}$, ,[...] Mischs „Geschichte der A.[utobiographie]” [...] deutet die autobiographischen Schriften seit der Antike als ,Zeugnisse für die Entwicklung des Persöhnlichkeitsbewusstseins der abendländischen Menschheit" [...]. Hingegen schreiben die Arbeiten aus den 1950er und 1960er Jahren (z.B. Pascal) die neuzeitliche Struktur der A. [utobiographie] im Sinne eines in sich geschlossenen, kohärenten lit. Werkes normativ fest. Neuere Ansätze betonen stattdessen den offenen, vielfältigen Charakter autobiographischer Erzählformen. (Мецлер 2007: 58-59).

${ }^{4}$ Исти топоси (аутопоетика, феминизам, мајка, љубав, детињство) карактеристични су и за поезију ове ауторке, како је већ примећено (Саша Јеленковић, на пример, у једној анкети Новости).

${ }^{5}$ Од многобројних наслова овде се наводе само неки: прва целовита биографија Драгише Васића историчара Милоша Тимотијевића, роман-хроника о детињству у Краљевини Југославији Ђорђа Лебовића Semper idem, али и Ja, тајкун Мирослава Мишковића који издавач рекламира као „уџбеник практичне економије”, затим авантуристичка прича у стилу Џемса Бонда „Био сам Титов шпијун” иначе анонимуса Драгише Ивеље или романсирана биографија рокера Нелета Карајлића Фајронт у Сарајеву која има и свој наставак у роману истог аутора Солунска 28.

${ }^{6} \mathrm{O}$ томе још пре десетак година пише Владимир Тасић у тексту „Алегорија колебљивог фундаменталисте", уп. Тасић 2018: 4.

${ }^{7}$ Ова Тасићева теза, примарно релевантна за САД, добија међутим, све више на важности уопште.
} 


\section{2. Романи-биографије и књижевност на граници жанрова}

Примера за ову врсту књижевних остварења све је више у и иначе богатој српској романескној продукцији. Стилизација и делимична фикционализација ову, „условно речено, биографску прозу” (Иван Ивањи) чине читљивијом и интересантнијом усмеравајући њену рецепцију у правцу документарног и евокације прошлости. При томе су очигледна жанровска преклапања ${ }^{8}$. Поред романсиране сопствене биографије какву налазимо у Мој лепи живот у паклу (2016) Ивана Ивањија, као и у ауторовој неколико година раније насталој књизи Титов преводилаи (2014), Ивањи у своје романе инкорпорира доживљено и фактографско, чиме настаје скоро мемоарско штиво. Тако се на пример у Писмима из Хаване говори о самиту несврстаних земаља чији је Ивањи био сведок, док су Ивањијеви сусрети са источнонемачким шефом службе државне сигурности Ерихом Милкеом уткани у роман Барбаросин Јеврејин у Србији. Један од разлога за такве и сличне поступке лежи у природи нарације, јер „начин казивања може бити ефектнији од истине” (Ивањи 2014: 11).

Ни Душану Ковачевићу такво схватање очигледно није страно:

Пет прича о нестајању, животу који се круни од ране младости, исписао сам као предговор књигама прича, романа, есеја, песама и као поговор раду од пола века.

Сећања на болести и несреће, чудом преживљене постала су опсесивни страхови јунака мојих драма, књига, филмова (Ковачевић 2017: 41).

Писац је притом свестан проблема разграничавања биографије и фикције, чега се експлицитно дотиче у Прилогу непостојећој биографији, скупу текстова раније објављиваних у НИН-у. Сличне провенијенције је и Шездесетосмаш Милисава Савића, збирка прича, репортажа, интервјуа објављиваних у Студенту 1968. године која није само сведочанство о једном историјском времену, већ и о књижевном сазревању њеног аутора9

Аутобиографског карактера је и роман Драгослава Михајловића Гори Морава, док је „Ујка Драги седи под јабуком”, да наведемо само један пример из Михајловићеве кратке прозе, лирски текст емотивног тона са јасно препознатљивим биографским предлошком. Биографске елементе налазимо у Школи за деликатне љубавнике (2018) Светлане Слапшак, као и у најновијем роману Владимира Арсенијевића Ка граници ${ }^{10}$. Ова и друга наведена дела, међутим, није примерено тумачити искључиво у биографском кључу, ма колико да се чинило да постоји оправдање за делимичан или мање-више

\footnotetext{
${ }^{8}$ Тако несвакидашњи пример биографије у драмској форми нуди Онај пас из Врања Зорана C. Николића који као предложак користи живот Врањанца Хаџи Тодора Димитријевића (18891977). У истом контексту је и књига Нине Живанчевић Оно што се памти, збирка путописних есеја , авангардне поетике, „књига са доста личног” како каже ауторка, а то обухвата сећање, сопствену идентитетску позицију и унутрашњи монолог Живанчевићеве са Анри Мишоом.

${ }^{9}$ То примећује и Радивоје Микић на промоцији књиге 2016. у Службеном гласнику.

${ }^{10}$ Радња романа одвија се у Грчкој 1992. године када је Арсенијевић путовао између Грчке и Србије, радећи као туристички водич.
} 
потпун позитивистички приступ анализи текста. Књижевне творевине су великим делом одраз животне стварности и историјског тренутка, делом са лако препознатљивим изворима књижевне грађе, тема и мотива, међутим формална и жанровска разноврсност отварају вишезначне и често сасвим супротне могућности интерпретације књижевног текста у нашем времену у коме преовладавају теоријски канони који су заменили оне књижевне. Тако (ауто)биографски дискурс, да се послужимо данашњим речником, свакако неће довести до оживљавања биографске критике (коју је како знамо неговао и Павле Поповић), која је модификована у психолошки и потом психоаналитички метод да би данас доживела друге модификације сагласно актуелним трендовима књижевне теорије ${ }^{11}$.

\section{3. Нове форме метафикције и питања жанра}

Нове форме метафикције карактеристичне за задње деценије 20. столећа и форсирано укидање жанровско-типолошких конвенција постају једна од главних карактеристика књижевне продукције не само у српској књижевности, већ и у другим књижевностима региона. У контексту истраживања актуелних културних а тиме и књижевних појава поставља се питање евентуалне промене до тада важеће парадигме, које би се одразило како на културну самосвест $^{12}$, тако и на жанровско-типолошке аспекте књижевних творевина.

Притом је од централног значаја очигледна стагнација жанровски „чистих" књижевних остварења. Како је познато, ради се о појави која је како традиционално присутна у јужнословенским књижевностима ${ }^{13}$, тако и условљена новим културним импулсима који долазе из глобалног круга. Тако је „феномен нултих” (Крешимир Багић) са завидном популарношћу, Фестивал алтернативне кьижевности или скраћено ФАК ${ }^{14}$ по Деану Дуди феномен популарне клупске културе (Дуда 2003: 57), а за приповедача и критичара Роберта Перишића реч је о симбиози књижевности и медија (Перишић 2003). Блогерска књижевност и тематски и формално веома разнолика блогосфера такође спадају у оно преузето из глобалне културе ${ }^{15}$. У неким случајевима реч jе о потпуно новом приступу креирању форме и садржаја и тиме о типолошким и жанровским иновацијама које другде не налазимо. Све ово одражава се и у науци. Промене језичке и нормативне свести и питања жанра последњих

\footnotetext{
${ }^{11}$ Питањима везаним за биографију и аутобиографију бавио се само у прошлом веку низ теоретичара, од Вилхелма Дилтаја, преко Фројда, Бориса Томашевског, Бахтина, Жана Старобинског и Пјера Бурдијеа, до Женета, Лежена и Дериде, да наведемо само најпознатија имена.

${ }^{12}$ Крешимир Багић у овом контексту говори о појавама које „недвојбено свједоче о тематској, поетичкој и стилској раскоши хрватскога романа у нултим годинама” (Багић 2016: 145).

${ }^{13}$ Које од почетка новог века континуирано партиципирају у развојним токовима европских књижевности.

${ }^{14}$ Покренут и осмишљен од стране Ненада Ризвановића, Хрвоја Освалдића и Боривоја Радаковића.

${ }^{15}$ О овој врсти књижевног деловања у Хрватској види Багић 2016: 155-156.
} 
година су тема књижевних истраживања теоријске природе ${ }^{16}$ као и важна ставка студија и монографија које се појављу у Србији и Хрватској ${ }^{17}$.

У овом контексту од посебног значаја је однос према жанровској нормативности у роману, који је sui generis хибридни жанр ${ }^{18}$. За немачке романтичаре и Карла Вилхелма Фридриха фон Шлегела роман је због своје способности интеграције различитих књижевних врста и рефлексије сопствене структуре парадигма онога што у оквиру свог програма означавају као „прогресивно универзалистичко поетско стваралаштво"19. Есејизација књижевних форми, пре свега романа, позната је још од Сервантеса и доживљава своју кулминацију у 18. веку $^{20}$. Други маркантан и познат пример интензивног присуства мешања жанрова и почетке интермедијалности ${ }^{21}$ нуди модерна и авангардни покрети на почетку прошлога века. На ове феномене упутио је као што знамо и Михаил Бахтин ${ }^{22}$. И коначно да се подсетимо, у постструктуралистичком смислу негира се постојање „чистих” жанрова, дакле све уметничке форме су „мешане”, хибридне ${ }^{23}$.

Примере жанровски хетерогене структуре налазимо и у савременом српском роману, оваква жанровска свест раздобља, да употребимо термин Владимира Битија (Бити 1997: 429), манифестује се и у кратким прозним формама.

${ }_{16}$ Један од примера је зборник Преплитања и укритања (хибридност у књижевности) објављен 2016, чији су уредници Бојан Јовић и Марија Шаровић, који говори о феномену хибрида у књижевности и мултимедијалним хибридима на примерима из француске, руске, немачке књижевности.

17 Попут студије Горана Радоњића Фикиија, метафикиија, нефикиија, Београд: Службени гласник 2016, у којој се аутор исцрпно бави хибридношћу савременог романа и мешањем жанрова. О делима која се „жанровски колебању” (стр. 112) говори и Крешимир Багић у свом Уводу у сувремену хрватску књижевност, Загреб: Школска књига 2016. Докторска дисертација Анере Ризнар, одбрањена на Загребачком свеучилишту 2013. бави се интердискурзивношћу у савременом хрватском роману. Бранислав Облучар аутор је текста о есеју као књижевном жанру (Облучар 2014) где се, између осталог, бави жанровски трансгресивним стваралаштвом Данијела Драгојевића, чији прозни текстови се могу читати као песме у прози и као есеји, при чему је фокус жанровске интерпретације често одређен премештањем идентичног текста из књиге песама у књигу есеја (Облучар 2014: 89). Драган Бошковић у једној својој студији пише о жанру Кишове Гробнице за Бориса Давидовича износећи тезу да ова књига може бити и роман и повест и збирка циклизованих прича (Бошковић 2004: 188). О проблематици жанра у Кишовим есејима види и Бечејски 2016. Слободанка Пековић бави се у својој студији Кюижевност у функиији 'принуде' часописима као фактором преобликовања књижевног текста и жанра.

${ }^{18}$ Радоњић 2016:119; у овој студији се веома прегледно и детаљно даје преглед историје мешања жанрова, уп. посебно Радоњић 2016: 119-132.

${ }^{19}$ „progressive Universalpoesie”, в. Мецлер 2007: 664.

${ }^{20}$ Бечејски 2016:50. Тога је био свестан и Данило Киш, уп. Бечејски 2016: 51.

${ }^{21}$ Која ће у глобалном оквиру свој пуни продор, али и почетак дебате о овом начину стваралаштва доживети почетком шездесетих година прошлога века.

${ }^{22}$ Бахтин 1989: 81, осим тога наравно и постмодернисти су се бавили овим питањем, да поменемо само Дериду.

${ }^{23}$ Одговарајући термини су hybridity, Mischformen, métissage. 


\section{4. Аутофикција, life writing, сећање као (ре)конструкција, живот као прича}

\section{1. Радмила Лазић: Угризи живот (2017)}

До сада једина књига прозних текстова ${ }^{24}$ песникиње Радмиле Лазић већ на први поглед открива чврсту формалну структуру и свесну композицију која од ње чини творевину на размеђи тематски везане веће прозне конструкције цикличног карактера и збирке кратких прича. Књига почиње на неконвенционалан начин, неком врстом свесне манипулације, усмеравања читаоца у правцу ишчитавања рекло би се, сасвим јасно животне приче ауторке ${ }^{25}$, која је међутим непоуздана и тера на опрез: „Не веруј ми. Не наседај. Ја то само подражавам живот."

Одмах потом следи оно централно: ради се о књижевној творевини, о фикцији, књижевном лику, фигури која само на тренутак, захваљујући нарацији израња из непостојања. Да би ауторка и поред свега узалудан покушај свођења животних рачуна материјализовала у нарацији, у неухватљивом и варљивом тексту јер живот је „Какав бестијаријум! Какво штиво!” - штиво које тражи не само свог читаоца, већ пре свега свог приповедача.

После кратког уводног текста из кога смо овде цитирали, симптоматичног наслова „Књижевна творевина”, следе кратке приче распоређене у пет одељака под називом Alter ego, Пенелопин синдром, Идентитети, Оне и Лирско бреме. Шест „Медитативних пасажа”, који су у оквиру одељака од кратких прича јасно одвојени курзивом, разликују се по садржају и обиму.

„Alter ego"26 почиње скицом истог назива у којој лако препознајемо сећање на некадашњу девојчицу, мада само један детаљ у опису (,носи доколенице") на то указује ${ }^{27}$. Слика, скоро идилична, већ садржи, међутим, упозорење на знаке трагике и смрти који су неизбежна компонента будућности и људског бивства.

Мотив alter ego-а као душе која повремено напушта тело, уз његово тумачење у етнолошком кључу, са поентом која указује на свевременско људских сумњи и страхова налазимо у „Ослушкивању”. Ови фрагменти из ауторкине унутрашње стварности ${ }^{28}$ указују на интроспективни карактер и биографску основу која се манифестује на различите начине. Текст може бити и набрајање стварних или фиктивних епизода из сопственог живота („Предсказања”), при чему све приче нису „сећање” како то показује „Принц на белом коњу” где се ауторка поиграва са стереотипним представама показујући свој

\footnotetext{
${ }^{24}$ Поред есејистичких текстова у Месту жудње (2005) и Мислити себе (2012).

${ }^{25}$ Сама ауторка у једном интервјуу говори о „припуштању живота у текст”, обрађивању животног материјала у књижевни, в. Вулићевић 2017: 13.

${ }^{26}$, „Друго ја”.

${ }^{27}$ Те индиректне, дискретне „сигнале” ауторка радо користи, како то показује и завршетак „Пустих жеља” из исте групе прича који нам открива да то зрела особа, већ близу животног краја, посећује места из детињства, или пак „Дописних љубави” где постаје очигледно да је реч о садашњем, архитектонски измењеном Скопљу.

28 Лазић на промоцији књиге у „Делфи кафеу” 19. септембра 2017.
} 
смисао за хумор. То поигравање лако прелази у црно-хуморни тон („Смрт на рате”, на пример). Аутобиографску везаност одсликавају опсесивне теме попут сопствене смрти („Колатерална жртва”) и смрти блиских особа („Место починка"), које су делом прави антрополошки медаљони и епизоде из живота ауторке („Сахране”, „Где становати”). Сусрећу се и фактографски, огољени описи, где се и формално, прецизним датирањем и нумерисањем реченица на пример, подвлачи набрајање и сугерише карактер списка, а не књижевног описа - тај „списак”, међутим, постаје лирска скица - остављајући нас у недоумици да ли је овде реч о „правом” или пак о „псеудоаутобиографском тексту” у коме се управо овакве формалије срећу („Радна соба. 1985”). Друга за аутобиографску прозу карактеристична тема је сећање, али не његова непоузданост и варљивост. Ауторка се фокусира на нашу склоност ка манипулацији и фалсификовању сећања („Доба пелена”). Њена сопствена сећања су, међутим, већином права - „Покретна кућица” евоцира честе, реалне селидбе у детињству, веродостојно делују и психолошке минијатуре попут оне у „Затуреним речима".

Хронолошки редослед реминисценција наставља се у „Пенелопином синдрому” онима из доба младости. Честа форма алегоријског казивања у овим психограмима сопственог ја ${ }^{29}$, тема љубави и „рекапитулација” емотивних веза и неостварених могућности живљења („Дописне љубави”), при чему неоствареност никако није нешто негативно јер су љубавне везе и заједнички живот пуни прозаичности, попут хркања (обично мушкарца) којем Радмила Лазић успева да навуче антрополошки образац који прелази у књижевно - или обрнуто („Хркање”). Реликвије сећања појављују се и у надреалистичким епизодама попут оне о одбеглој идеји у истоименој краткој причи која је (идеја) као одбегли муж.

У делу збирке означеном са „Идентитети” чини се да ауторка напушта аутобиографски дискурс постајући посматрач туђих живота где нема јасне границе између несреће и среће (,,(Не)срећа старе девојке”) и где страст лако прелази у агресију, разоткривајући лажну идилу („Туђа недеља”). Животни ломови и бродоломи других, живот парова је оно што ауторка посматра и описује. Али то су истовремено и слике из њеног сопственог, хипотетичког живота. Свет данашњице и свакодневица у Србији, импресије са Зеленог венца и београдских улица пружају туробну слику: старци клошари и усамљени и напуштени стари људи и пензионери, који једва састављају крај с крајем, Ром и Ромкиња, просјаци и остарели рокери, невољници и избеглице, „мали монструми" од деце, остарели љубавници, средовечни мушкарци у кризним годинама. Сировост и некултура у градском превозу. Фацит: туробан свет, туробан живот - али и ту се појављује аутопоетска инстанца, и у њему има страсти и жудње, снова и жеља, па тако и оних забрањених („Табу”). Све ово делује реалистички, без да се тврди да је стварност у Србији искључиво таква. Мада се јасно показује она корелација са стварношћу о којој је у уводном

${ }^{29}$ „Добила сам ћерку”: поставља се питање говори ли овде (бездетна) приповедачица и песникиња о својој касној прози. 
делу било речи, исто тако је очигледно да је реч о субјективном доживљавању и о „исечку” из актуелне свакодневице који приказује само неке од фасета живота у овом делу света. Тиме се такође подвлачи биографска подлога књижевног текста, њена есејистичко-рефлексивна грана.

Кратке приче сакупљене под одредницу „Оне” баве се женском егзистенцијом, при чему су честе паралеле са ставовима и темама (љубав, секс у екстремном или неуобичајеном контексту) аустријске феминисткиње и списатељице Елфриде Јелинек, осим тога, одговарајући пети „Медитативни пасаж" чине искључиво цитати из њених текстова. Деменција и старост мајке једна је од централних тема новије српске и других књижевности у региону $^{30}$, али и код Радмиле Лазић, која нам предочава горку истину оних који негују дементне родитеље („Мама”31) и која читав низ текстова посвећује овој теми.

Завршни циклус кратких прича бави се носталгијом за родним крајем, младошћу, чежњом за прошлим која је пратилац зрелог доба када се неумитно приближава крај животног пута. Сећања на (идиличне) пределе детињства и младости, кроз лирску призму виђена животна свакодневица, евокација прошлих времена и места попут биоскопа „Јадран” и сећања на познату београдску посластичарницу „Код коња”, сливају се у интимистички текст „Ко сам”, онтолошку запитаност бића, загонетку бивства која поништава трајање и време: „Старица сам што храни голубове. Девојчица сам што кида латице цвета воли-ме-не-воли-ме. Остављена сам вољена сам жена."

\section{2 Горан Петровић: Разлике (2009)}

Прозу сакупљену у збирку Разлике Горана Петровића чини пет тематски повезаних целина, дужих прича које су поднасловима подељене на мање епизоде. Први циклус тако структурисаних текстова сугерише биографски предложак и представља пример аутофикције. За разлику од других прича у књизи, поднаслови су повезани у хронолошки одређену целину, при чему се сваки од њих односи на једну годину живота приповедача, све до закључно двадесет и друге. Полазни топос је увек фотографија, а тематизује се по правилу нешто истовремено типично за одређено животно доба и тиме често у сфери стереотипа, али и индивидуално чиме се ствара илузија веродостојности или ако хоћемо „псеудоаутобиографског” дискурса. Тако „Црвенкаста нит - година прва” уводи поред слике голишаве бебе и црвенкасти кончић који је дечак извукао из зидне таписерије поред које су га сликали. Мада овде очигледно фикционално потире фактографско (фотографија наи-

\footnotetext{
${ }^{30}$ Упореди Арзамас Иване Димић, Божанску дјечииу Татјане Громача, Косу посвуда Тее Тулић, Сатове у мајчиној соби Тање Ступар Трифуновић.

${ }^{31}$ Деца остареле мајке чекају да она умре, долази до очекивања и прижељкивања смрти као разрешења.
} 
ме може бити само црно-бела уколико изједначимо приповедача и аутора), (ре)конструкција прошлог делује у деловима приче који следе подупрта сећањем и пре свега повезивањем са садашњим тренутком ${ }^{32}$. У запису о „години петој" на полеђини фотографије са летовања је датум који се поклапа са подацима из живота 1961. године рођеног аутора. И у завршној епизоди која се односи на 22. годину живота приповедача такође се датирање, прецизно дано већ у првој реченици (Петровић 2009: 26), уклапа у стварни живот аутора. Осим тога, што се приповедање више ближи крају, све су бројнија и наглашенија укључивања фактографског у књижевно дело, да би се прича завршила текстом о настанку и објављивању првог нараторовог прозног рада, приче „Со”,33, у фиктивном часопису „Октобар” који излази у пишчевом родном граду. Спретним преплитањем фикције и фактографског, модификујући притом аутобиографски приступ, Горан Петровић нам предочава слику једног времена, оживљену укључивањем сопственог животног искуства и личне интиме, на граници аутофикције, приповедања и маште.

\section{ЛИТЕРАТУРА}

Арсенијевић 2018: В. Арсенијевић, Ка граници, Београд.

Бахтин 1989: М. Бахтин, О роману, Београд.

Багић 2016: K. Bagić, Uvod u suvremenu hrvatsku književnost 1970-2010, Zagreb.

Бечејски 2016: М. Бечејски, Есејистика Данила Киша, докторска дисертација, Универзитет у Нишу, Филозофски факултет, Ниш.

Бошковић 2004: Д. Бошковић, Иследник, сведок, прича и истражни поступци у Пешчанику $и$ Гробници за Бориса Давидовича, Београд.

Бити 1997: V. Biti, Pojmovnik suvremene književne teorije, Zagreb.

Вулићевић 2017: М. Вулићевић, „Не посматрам живот из мишје рупе”, у: Политика, 18. септембар 2017, 13.

Громача 2012: T. Gromača, Božanska dječica, Zagreb.

Живанчевић 2017: Н. Живанчевић, Оно што се памти. Индијски дневник, Београд: Корнет.

Димић 2017: И. Димић, Арзамас, Београд 2017.

Дуда 2003: D. Duda, „Fak na konac”, y: Feral tribune, 20.12.2003, 54-59.

Ивањи 1984: И. Ивањи, Писма из Хаване, Београд.

Ивањи 1998: И. Ивањи, Барбаросин Јеврејин у Србији, Београд.

Ивањи 2014: И. Ивањи, Титов преводилаи, Београд.

Ивањи 2016: И. Ивањи, Мој лепи живот у паклу, Београд.

Ивеља 2017: Д. Ивеља, Био сам Титов шпијун, Београд.

32 Приповедач наиме наводи да његова кћи има исту потребу да „чепрка кажипрстом” иза зидне таписерије, уп. Петровић 2009: 6.

${ }^{33}$ Петровић има причу тог наслова, насталу међутим много касније и уврштену у књигу „записа" Претраживач. 
Јовић и Шаровић 2016: Преплитања и укритања (хибридност у књижевности), уредници Бојан Јовић и Марија Шаровић, Београд: Институт за књижевност и уметност.

Карајлић 2014: Н. Карајлић, Фајронт у Сарајеву, Београд: Лагуна.

Карајлић 2018: Н. Карајлић, Солунска 28, Београд: Лагуна.

Ковачевић 2008: Д. Ковачевић, Прилог непостојећој биографији, Београд.

Ковачевић 2017: Д. Ковачевић, Двадесет српских подела, Београд.

Кордић 2000: Р. Кордић, Аутобиографско приповедағе, Београд.

Лазић 2005: Р. Лазић, Место жудње, Београд.

Лазић 2012: Р. Лазић, Мислити себе, Вршац: КОВ.

Лазић 2017: Р. Лазић, Угризи живот, Београд.

Лебовић 2005: Ђ. Лебовић, Semper idem, Београд 2005.

Лежен 1994: Ph. Lejeune, Der autobiographische Pakt (frz. 1975), Frankfurt/M.

Мецлер 2007: Metzler Lexikon Literatur 2007: Schwalm, Helga, Autobiographie, $57-59$.

Михајловић 1994: Д. Михајловић, Гори Морава, Београд.

Мишковић 2018: М. Мишковић, Ja, тајкун, Београд: Лагуна.

Николић 2018: 3. С. Николић, Онај пас из Врања, Врање.

Облучар 2014: B. Oblučar, ,'Kondicionalna istina' esej kao književni žanr”, y: Umjetnost riječi, LVIII/2014,1, siječanj-ožujak, 75-90.

Пековић 2010: С. Пековић, Кюижевност у функиији „принуде”. Часопис као фактор преобликовања књижевног текста и жанра, Београд.

Перишић 2003: R. Perišić, „Finale FAK-ova reality showa”, y: Globus, 19.02.2003.

Петровић 2009:Г. Петровић, Разлике, Београд: Плато.

Петровић 2017: Г. Петровић, Претраживач. Записи, Београд: Службени гласник.

Радоњић 2016: Г. Радоњић, Фикиија, метафикција, нефикиија. Модели приповедања у српском и америчком роману шездесетих и седамдесетих година 20. вијека, Београд.

Ризнар 2013: A. Ryznar, Interdiskurzivnost u suvremenom hrvatskom romanu, doktorski rad, Zagreb, Filozofski fakultet.

Савић 2016: М. Савић, Шездесетосмаш, Београд.

Слапшак 2018: С. Слапшак, Школа за деликатне љубавнике, Београд: Лагуна. Ступар Трифуновић 2014: T. Stupar Trifunović, Satovi u majčinoj sobi, Sarajevo.

Тасић 2018: В. Тасић, „Алегорија колебљивог фундаменталисте”, у: Ламед, $11 / 2018,8,1-12$.

Тимотијевић 2017: М. Тимотијевић, Драгища Васић (1885-1945) и српска национална идеја, Београд: Службени гласник.

Типнер, Лаферл: 2016: A. Tippner, Ch. F. Laferl, Texte zur Theorie der Biographie und Autobiographie, Herausgegeben und eingeleitet von Anja Tippner und Christopher F. Laferl, Stuttgart.

Тулић 2011: T. Tulić, Kosa posvuda, Zagreb.

Шнајдер 1986: M. Schneider, Die erkaltete Herzenschrift. Der autobiographische Text im 20 Jahrhundert, München. 


\section{Vesna Cidilko}

\section{DIE VARIATIONEN DES BIOGRAPHISCHEN UND DIE GATTUNGSFRAGE IN DER SERBISCHEN PROSA DER GEGENWART}

\section{(Zusammenfassung)}

Die Ausführungen fokussieren sich auf die Rolle und die Funktion des biographischen Zugangs vor allem in kurzen Prosaformen zeitgenössischer serbischer Autoren. Dabei wird neben einer Analyse der thematisch-motivischen Strukturen der Texte auch der Gattungsfrage nachgegangen. 